BMC

Cell Biology

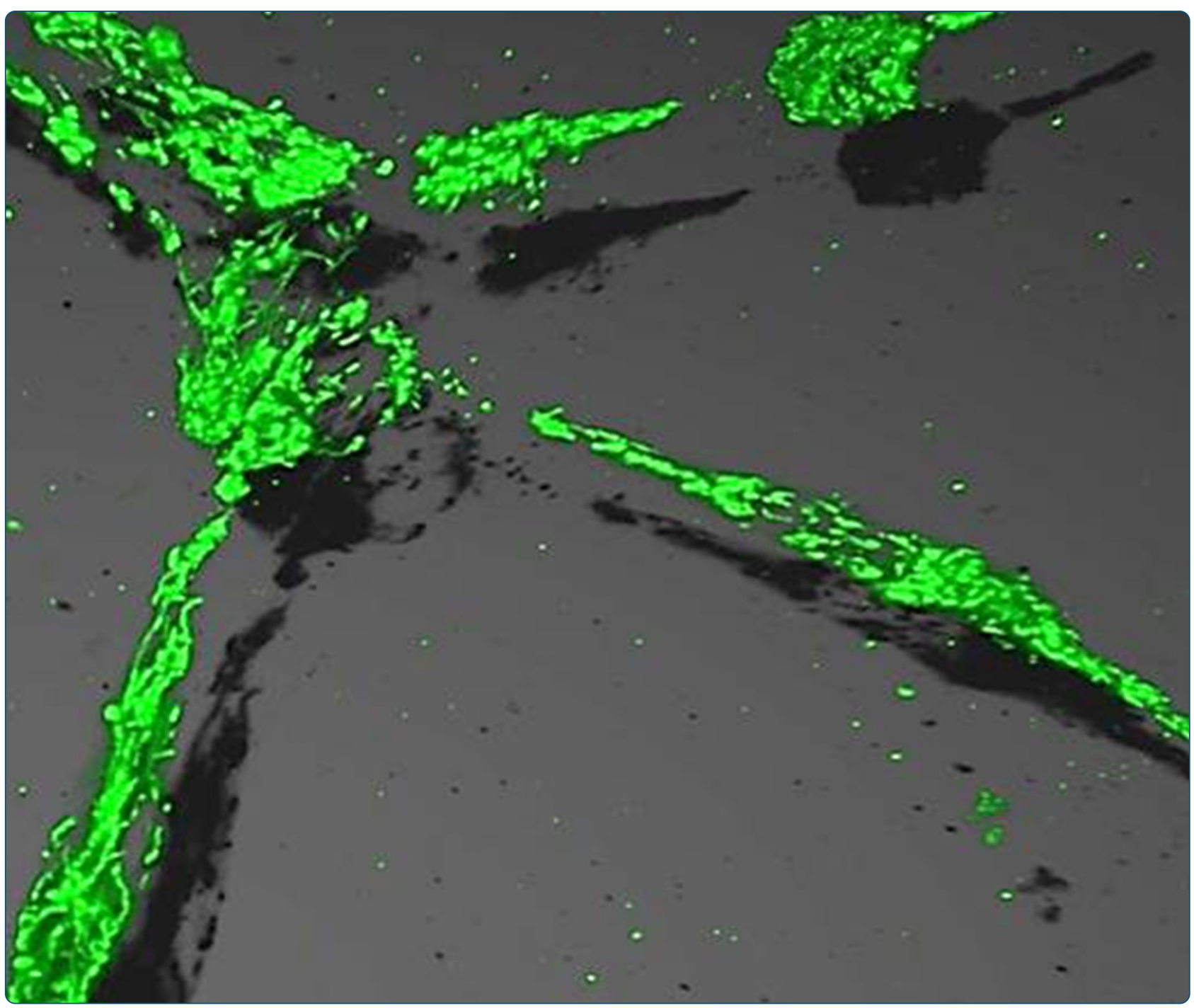

A thin layer angiogenesis assay: a modified basement matrix assay for assessment of endothelial cell differentiation

Faulkner et al.

C Biomed Central 


\title{
A thin layer angiogenesis assay: a modified basement matrix assay for assessment of endothelial cell differentiation
}

\author{
Ashton Faulkner ${ }^{1}$, Robert Purcell ${ }^{1}$, Andrew Hibbert ${ }^{1}$, Sally Latham', Scott Thomson', Wendy L Hall2, \\ Caroline Wheeler-Jones ${ }^{1}$ and David Bishop-Bailey ${ }^{1 *}$
}

\begin{abstract}
Background: Basement matrices such as Matrige $\mathrm{I}^{\mathrm{TM}}$ and Geltrex ${ }^{\mathrm{TM}}$ are used in a variety of cell culture assays of anchorage-dependent differentiation including endothelial cell tube formation assays. The volumes of matrix recommended for these assays (approximately $150 \mu \mathrm{l} / \mathrm{cm}^{2}$ ) are costly, limit working distances for microscopy, and require cell detachment for subsequent molecular analysis. Here we describe the development and validation of a thin-layer angiogenesis (TLA) assay for assessing the angiogenic potential of endothelial cells that overcomes these limitations.

Results: Geltrex ${ }^{\mathrm{TM}}$ basement matrix at $5 \mu \mathrm{l} / \mathrm{cm}^{2}$ in 24-well $(10 \mu \mathrm{l})$ or 96 -well $(2 \mu l)$ plates supports endothelial cell differentiation into tube-like structures in a comparable manner to the standard larger volumes of matrix. Since working distances are reduced, high-resolution single cell microscopy, including DIC and confocal imaging, can be used readily. Using MitoTracker dye we now demonstrate, for the first time, live mitochondrial dynamics and visualise the 3-dimensional network of mitochondria present in differentiated endothelial cells. Using a standard commercial total RNA extraction kit (Qiagen) we also show direct RNA extraction and RT-qPCR from differentiated endothelial cells without the need to initially detach cells from their supporting matrix.

Conclusions: We present here a new thin-layer assay (TLA) for measuring the anchorage-dependent differentiation of endothelial cells into tube-like structures which retains all the characteristics of the traditional approach but with the added benefit of a greatly lowered cost and better compatibility with other techniques, including RT-qPCR and high-resolution microscopy.
\end{abstract}

Keywords: Angiogenesis, Endothelial cell, Basement matrix, Mitochondria, PPAR, VEGF

\section{Background}

Secreted extracellular matrix proteins, purified from the Engelbreth-Holm-Swarm (EHS) tumour, such as Matrigel ${ }^{\mathrm{Tn}}$ and Geltrex ${ }^{\text {tix }}$, are widely used in a variety of cell culture applications [1-4], including the support of primary cell propagation, and anchorage-dependent cell differentiation. These cell differentiation assays include the morphogenesis of endothelial cells (EC) into tube-like structures (tube-formation assay) for the study of in vitro angiogenesis [3,5,6], and the differentiation of neural cells in neurite outgrowth assays [1].

\footnotetext{
* Correspondence: dbishopbailey@rvc.ac.uk

${ }^{1}$ Comparative Biomedical Sciences, Royal Veterinary College, University of London Royal College Street, London NW1 OTU, UK

Full list of author information is available at the end of the article
}

The most common assay employed using basement matrix is the EC tube formation assay, thought to represent the differentiation stage of angiogenesis and often being applied as a first-pass screening assay of compounds with potential pro- or anti-angiogenic properties (reviewed in Staton et al., 2009 [7]). To study cell differentiation, a relatively large volume of matrix is usually indicated with recommendations and common usage of matrix in the order of $50-200 \mu \mathrm{l} / \mathrm{cm}^{2}$, depending upon the assay to be employed. As well as increasing the general cost associated with performing these assays this volume of matrix also precludes the use of experimental techniques such as highresolution/single cell microscopy and requires further cell manipulation (e.g. dispase digestion) [8] in order to extract mRNA for subsequent gene expression analysis. In an 
attempt to solve these issues we sought to develop a thin layer angiogenesis assay (TLA) that would retain the ability to act as an anchoring and differentiating platform, but could also be used for high definition single cell imaging. Here, we show that spreading low volumes of Geltrex ${ }^{\text {max }}$ basement membrane thinly onto glass or tissue culture plastic enables the use of high-resolution imaging and direct RNA extraction from endothelial cells that are actively engaged in the tube-forming process. This simple assay generates comparable data to those derived from large volume matrix assays, and has a far greater utility in terms of imaging and transcriptional analysis accompanied by a $25-30$ fold reduction in relative cost.

\section{Results}

The human endothelial cell line (EA.hy926) and primary human umbilical vein endothelial cells (HUVEC) undergo differentiation on a thin layer matrix

$10 \mu \mathrm{l}$ of growth factor-reduced Geltrex ${ }^{\mathrm{Tx}}$ basement matrix was spread evenly onto glass (13 mm coverslip) using a sterile syringe insert. HUVEC or EA.hy926 formed tubelike structures under non-stimulated conditions (vehicle alone; $0.01 \%$ DMSO) and the number of tubes formed was significantly increased in response to the distinct angiogenesis inducers vascular endothelial growth factor (VEGF; $25 \mathrm{ng} / \mathrm{ml})$ and GW0742 $(1 \mu \mathrm{M})$, a selective PPAR $\beta / \delta$ agonist [3,6] (Figure 1). Similar results were obtained when Geltrex $^{\text {ma }}$ matrix was spread directly onto tissue culture plastic with VEGF-stimulated HUVEC showing a clear proangiogenic response (Figure 2).

An advantage of the traditional angiogenesis assay is scalability, with many research groups performing the assay in a 96-well plate format using $50 \mu \mathrm{l} /$ well of basement matrix [6,9-11]. To determine if this higher throughput can be achieved with the TLA assay, HUVEC $(25,000$ cells $/ \mathrm{cm}^{2}$ ) were seeded on $2 \mu \mathrm{l}$ of Geltre ${ }^{\mathrm{Tm}}$ basement matrix in the presence of VEGF $(25 \mathrm{ng} / \mathrm{ml} ; 16 \mathrm{~h})$ or GW0742 (100 nM; $16 \mathrm{~h})$. These experiments showed that responses to VEGF and GW0742 using the TLA in 96-well plate format (Figure 3) were identical to those measured using the coverslip TLA approach (Figure 1).

A common goal for those routinely using the basement matrix assay for assessing angiogenic potential is the use of automated quantification systems. The use of an automated quantification system (ImageJ Angiogenesis Analyzer) provides qualitatively but not always quantitatively identical data to manual counting (Figure 4; Additional file 1: Table S1).

\section{The TLA approach is qualitatively similar to the traditional thick layer approach}

To make a direct comparison of the TLA approach with the traditional thick layer, HUVEC were stimulated to undergo tubulogenesis in the presence or absence of
VEGF $(25 \mathrm{ng} / \mathrm{ml})$ on either $2 \mu \mathrm{l} /$ well or $50 \mu \mathrm{l} /$ well of Geltrex $^{\text {ma }}$ in a 96-well format. VEGF induced a similar pro-angiogenic effect on HUVEC whether on a standard thick or TLA basement matrix (Figure 5; Additional files 2: Movie S1A and S1B).

\section{Differential interference contrast (DIC) and confocal microscopy of differentiated endothelial cells}

Unlike cell monolayers, the traditional tube formation assay with its large matrix volume has greatly reduced microscopic working distances, making single cell analysis highly challenging. Using HUVEC stimulated with VEGF $(25 \mathrm{ng} / \mathrm{ml} ; 16 \mathrm{~h})$ in $35 \mathrm{~mm}$ glass-bottom plates coated with $10 \mu \mathrm{l}$ of Geltrex ${ }^{\mathrm{mm}}$, differential interference contrast (DIC) images were acquired using a Zeiss Axiovert 135 microscope ( $\times 20$ objective). As shown in Figure 6A the TLA is clearly compatible with use of this high contrast technique.

As proof-of-principle for live single cell and confocal imaging we chose the well-established mitochondrialspecific dye MitoTracker [12]. VEGF-stimulated HUVEC $(25 \mathrm{ng} / \mathrm{ml} ; 16 \mathrm{~h})$ were incubated for $40 \mathrm{~min}$ with MitoTracker green $(200 \mathrm{nM})$. Live mitochondrial dynamics (over $10 \mathrm{~min}$; $\times 63$ objective) were recorded within the tube-like structures (Figure 6B and Additional file 3: Movie S2). In addition to single cell-live imaging, the 3D mitochondrial network in differentiated endothelial cells was reconstructed following z-stack deconvolution ( $\times 40$ objective) using a Leica SP5 confocal microscope (Figure 6C and Additional file 4: Movie S3).

To demonstrate confocal imaging of fixed cells, HUVEC differentiated using the TLA approach in chamber slides (VEGF $25 \mathrm{ng} / \mathrm{ml} ; 16 \mathrm{~h}$ ) were fixed with 4\% PFA and stained for the common endothelial cell marker CD31 (PECAM) (Figure 7 and Additional file 5: Movie S4).

\section{Direct RNA extraction from HUVEC in the TLA assay for use in RT-qPCR}

Total RNA was extracted from HUVEC differentiated into tubes using the TLA assay following exposure to VEGF (25 ng/ml) without prior cell isolation according to the manufacturer's recommended protocol (Qiagen Total RNA Extraction kit). Subsequent standard RT-qPCR analysis readily detected GAPDH and COX-2 expression (previously shown to increase in HUVEC in response to VEGF treatment [6]). COX-2 expression in the TLA was not significantly induced relative to GAPDH at $16 \mathrm{~h}$ in VEGF stimulated tube-forming HUVEC (Figure 8 and Additional file 6: Figure S2).

\section{Discussion}

The use of a basement matrix in the study of anchoragedependent differentiation is common place in many research laboratories, with the endothelial cell tube formation 

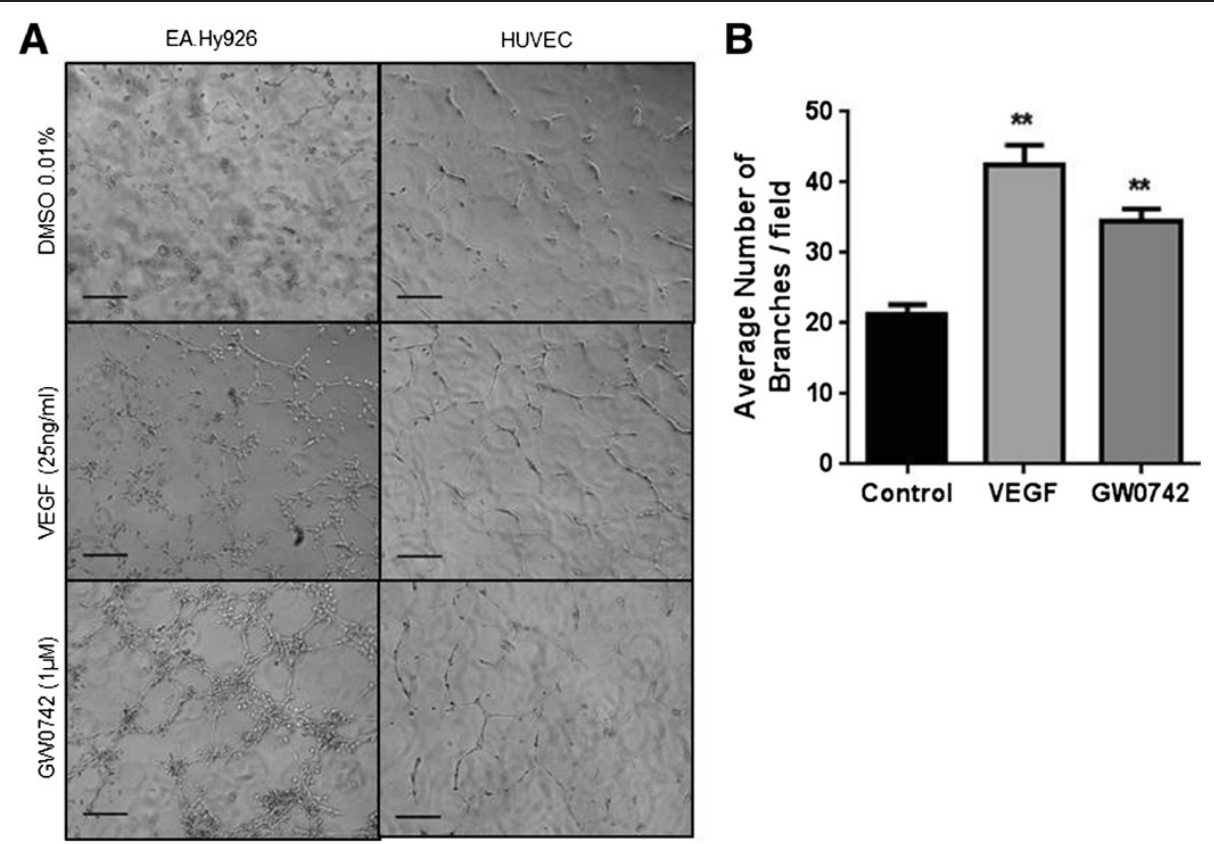

Figure 1 Human endothelial cells readily differentiate on thin layers of basement matrix spread on glass. (A) Representative images of EA.hy926 and HUVEC forming tube-like structures after 24 and 16 hours, respectively, when plated onto $10 \mu / / 2 \mathrm{~cm}^{2}$ of basement matrix in the presence of VEGF $(25 \mathrm{ng} / \mathrm{ml}$ ) or GW0742 (1 $\mu \mathrm{M})$. Images were acquired using Leica DMIRB microscope (x10 objective). Scale bar $=200 \mu \mathrm{m}$. (B) Quantification of tubes formed by HUVEC at 16 hours in the presence of VEGF, GW0742 or DMSO control. Data represent mean ( \pm S.E.M) number of branches/field from $n=5$ separate donors. ${ }^{* *} p<0.01$ vs. DMSO control as determined by repeated measures ANOVA followed by Dunnett's post analysis.

assay being the most widely used in vitro assay for the study of angiogenesis. The smallest volume of matrix used in this assay to date is $15 \mu \mathrm{l} / \mathrm{cm}^{2}$ (30 $\mu \mathrm{l}$ per well of a 24-well plate) [13] which is more cost effective than the recommended volume of $50 \mu \mathrm{l} / \mathrm{cm}^{2}$ (100 $\mu \mathrm{l}$ per well of a 24-well plate) but created a meniscus that promoted cell pooling [14]. In theory, if the matrix layer becomes thin enough, significant meniscus formation and subsequent cell pooling would be overcome. Here, we demonstrate that the use of as little as $5 \mu \mathrm{l} / \mathrm{cm}^{2}$ (10 $\mu \mathrm{l}$ per well of a 24-well plate) is sufficient to support the anchorage-dependent differentiation of endothelial cells into tube-like structures without meniscus formation and cell pooling. Using this thin layer approach we demonstrate that the assay can be reproducibly performed on glass or on plastic and that quantification of tube-forming capacity shows the expected pro-angiogenic responses to VEGF and the PPAR $\beta / \delta$ agonist GW0742 (Figures 1, 2, 3 and 5), consistent with published data from our and other laboratories using a traditional matrix volume $[3,6,15,16]$ and re-confirmed in side-by-side comparisons in this paper (Figure 5). Moreover, the TLA method may provide a platform for more stable tube formation with less network breakdown (Additional file 2: Movie S1). The reason for this is not clear but may represent a further potential advantage over the traditional thick layer approach.

A common problem with the standard assay is its compatibility with automated analysis systems due to loss of focus, predominantly as a consequence of meniscus formation. With the TLA method reducing meniscus formation we sought to identify if automated analysis using the Image J Angiogenesis Analyzer freeware was compatible with this thin layer approach. Automated analysis was qualitatively (if not always quantifiably) similar to manual counting (Figure 4), and can therefore (with this caveat) be readily applied to the TLA method.

An additional benefit of using the TLA assay in a 24-well format is the ability to directly extract mRNA from the tube-forming cells for gene expression analysis. Traditionally, due to the large volume of gel present this has been achieved by isolating the cells from the matrix (e.g. by dispase digestion) which requires subjecting the cells to additional chemical treatment and centrifugation $[8,17]$. Accordingly, most studies investigate gene expression in endothelial cell monolayers and correlate the results with outcomes from the functional tube formation assay $[3,18,19]$. With the highly reduced gel volume, the TLA approach presented here negates the need for cell detachment from the matrix, thus allowing direct extraction of RNA from cells which are undergoing or have completed tubulogenesis. This modification therefore makes the molecular analysis less time-consuming as well as circumventing the difficulties associated with extrapolating between data derived from cell monolayers versus differentiating endothelial cells. The ability to increase throughput 


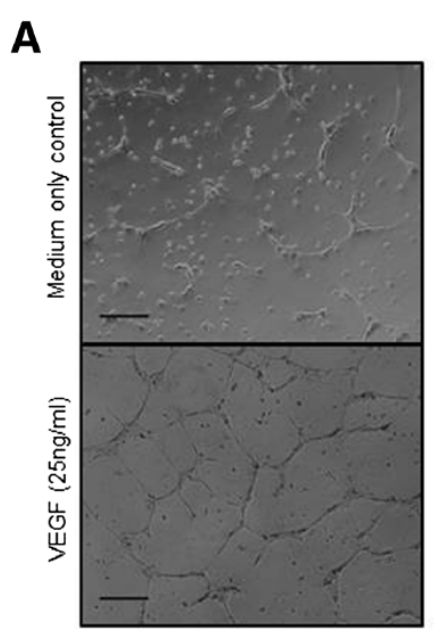

B

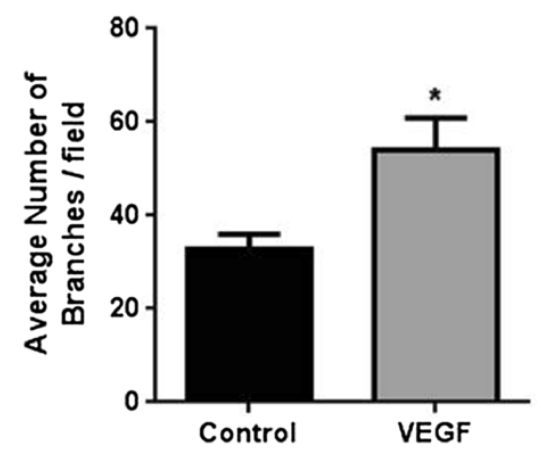

Figure 2 Human endothelial cells readily differentiate on thin layers of basement matrix spread on tissue culture plastic. (A) Representative images of HUVEC forming tube-like structures after 16 hours when plated onto $10 \mu \mathrm{l} / 2 \mathrm{~cm}^{2}$ of basement matrix in the presence of VEGF ( $25 \mathrm{ng} / \mathrm{ml}$ ) or medium only control. Images were acquired using Leica DMIRB microscope (x10 objective). Scale bar $=200 \mu \mathrm{m}$. (B) Quantification of branches formed by HUVEC at 16 hours in the presence of VEGF, or medium control. Data represent mean ( \pm S.E.M) number of branches/field from $n=4$ separate donors. ${ }^{*} p<0.05$ vs. medium control as determined by paired Student's $t$-test.

is an advantage for any assay, particularly when it may be desirable to screen the effects of a number of different compounds. In this respect we show that the TLA methodology can be used in a higher throughput format in 96-well plates using $2 \mu \mathrm{l}$ of matrix/well (Figure 3).
The ability to obtain high-resolution images from a convenient low-cost in vitro assay is highly desirable. We show here that one of the advantages of the TLA assay with its greatly reduced working distances is the use of high-resolution microscopy, including DIC and
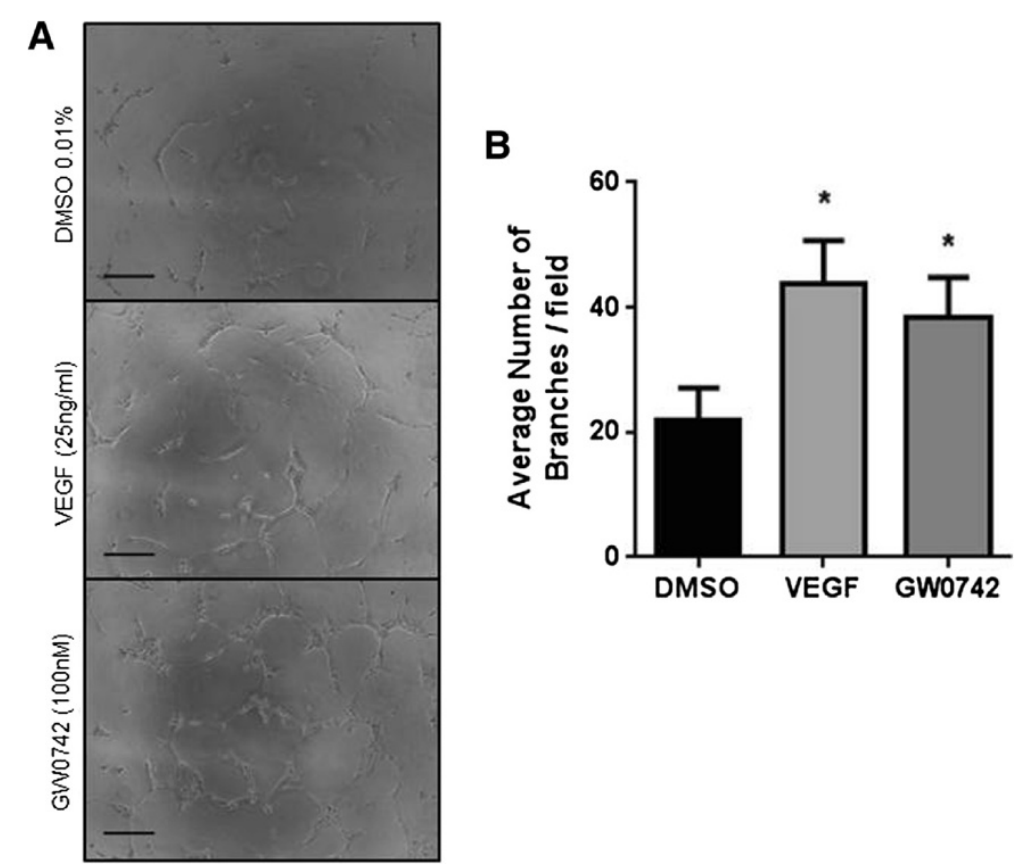

Figure 3 The thin-layer angiogenesis assay (TLA) can be performed in a 96-well plate format using $2 \mu \mathrm{l}$ of basement matrix. (A) Representative images showing HUVEC $\left(25,000 \mathrm{cells} / \mathrm{cm}^{2}\right)$ forming tube-like structures after 16 hours when plated onto $2 \mu$ l of basement matrix with more tubes forming in the presence of VEGF $(25 \mathrm{ng} / \mathrm{ml})$ or GW0742 (100nM). Images were acquired using Leica DMIRB microscope (x10 objective). Scale bar $=200 \mu \mathrm{m}$. (B) Mean number of branches ( \pm S.E.M)/field formed at 16 hours in the presence of VEGF (25 ng/ml), GW0742 $(100 \mathrm{nM})$ or DMSO control. * $p<0.05$ vs. DMSO control as determined by repeated measures ANOVA followed by Dunnett's post analysis, $\mathrm{n}=6$ separate donors ran in sextuplet. 

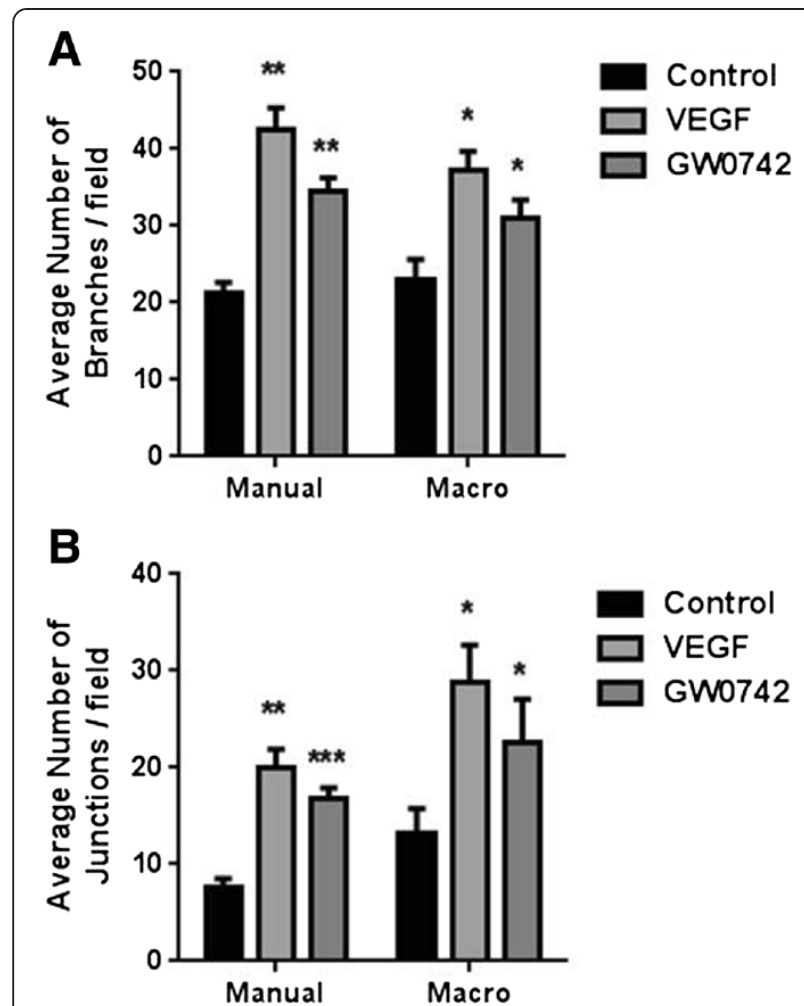

Figure 4 Comparison of manual versus automated quantitation of angiogenic parameters. A comparison of (A) average number of branches/field and (B) average number of junctions/field obtained from the 24-well data acquired from the HUVEC TLA experiments reported in Figure 1 when quantified manually or with the use of the angiogenesis macro for Image J. $\mathrm{n}=5$ independent donors. ${ }^{*} p<0.05{ }^{* *} p<0.01{ }^{* * *} p<0.001$ vs control as determined by one-way ANOVA followed by Dunnett's post-analysis test.

confocal, that allows a more accessible means of studying cellular and intracellular processes, demonstrated here by the immunofluorescent staining of CD31. Moreover, with the growing interest in the role played by cell organelles such as the mitochondria in the angiogenic process [20,21], we have successfully monitored the mitochondrial network and dynamics during endothelial cell tubulogenesis. To our knowledge we are the first to show such high-resolution images of live mitochondria within developing tubules.

\section{Conclusions}

The use of a basement matrix in the study of anchoragedependent differentiation is common place in many research laboratories, with the endothelial cell tube formation assay being the most widely used in vitro assay for investigating the angiogenic functions of endothelial cells. Current recommended matrix volumes make this an expensive assay, preclude the use of more advanced imaging techniques, and limit the ease with which molecular data can be acquired. We have described a modified method for this basement matrix assay which provides all the necessary support required for differentiation, generating results which are similar to those obtained using the traditional approach. In conclusion, our thin layer angiogenesis assay makes for the ideal first-pass angiogenesis screening assay with a substantially lowered cost (25-30 fold) compared to commonly used similar in vitro angiogenesis assays, whilst at the same time maximising high through put testing, and gives the user greatly reduced working distances that allows, for the first time with this assay, single cell, high resolution imaging of actively differentiating cells.

\section{Methods}

\section{Cell culture}

EA.Hy926 cells were cultured in Dulbecco's Modified Eagles Medium (DMEM) (Sigma Aldrich, Gillingham, UK) supplemented with $10 \%$ foetal bovine serum (FBS) and $1 \%$ penicillin/streptomycin (Pen/Strep) at $37^{\circ} \mathrm{C}, 5 \% \mathrm{CO}_{2}$. Unless stated, experiments were carried out in serum-free DMEM (1\% pen/strep). Human Umbilical Vein Endothelial Cells (HUVEC) were isolated from donated cords as previously described [6] and cultured under standard
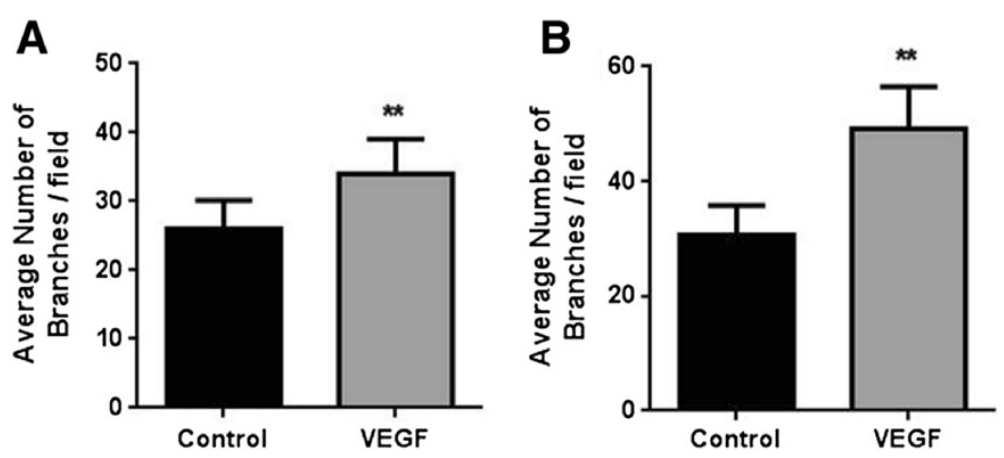

Figure 5 Direct comparison of the thin layer angiogenesis (TLA) assay with standard thick layer assay. Comparison of the average number of branches/field (manual count) formed by HUVEC $\left(25,000 \mathrm{cells} / \mathrm{cm}^{2}\right)$ in the presence or absence of VEGF $(25 \mathrm{ng} / \mathrm{ml})$ in the standard thick layer assay (A) and the TLA assay (B). ${ }^{* *} p<0.01 \mathrm{vs}$. control as determined by student's paired t-test. 


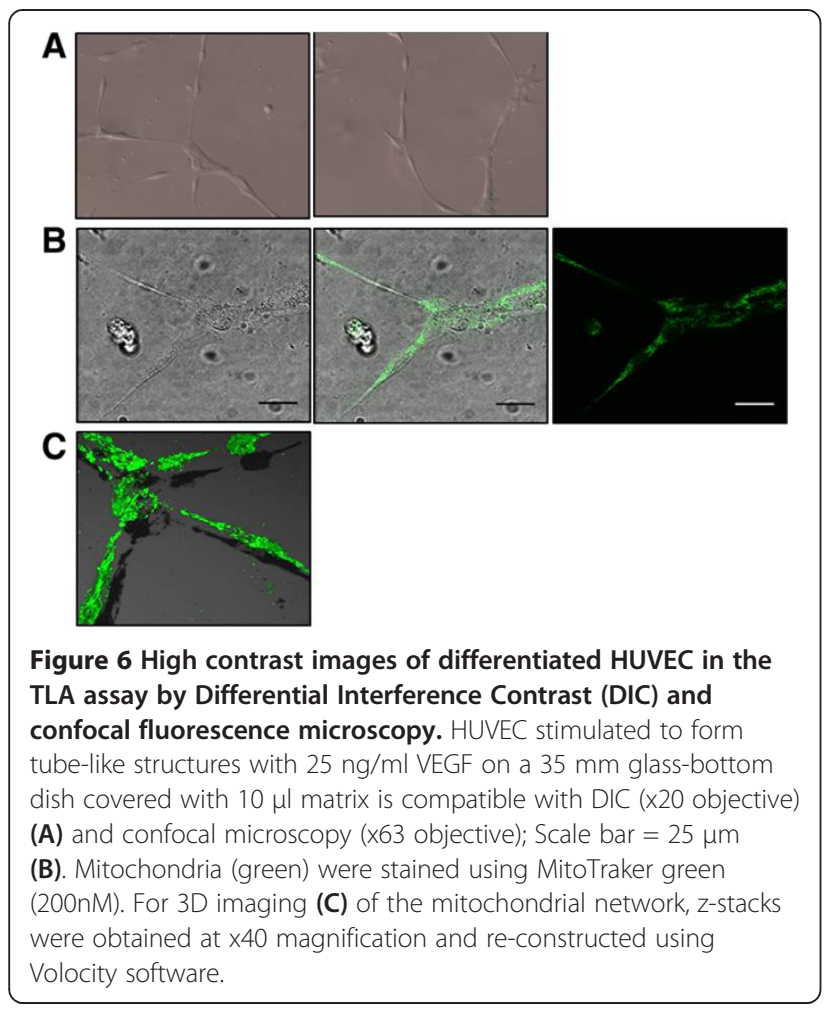

conditions $\left(37^{\circ} \mathrm{C}, 5 \% \mathrm{CO}_{2}\right)$ in $\mathrm{M} 199$ supplemented with $20 \mu \mathrm{g} / \mathrm{ml}$ endothelial cell growth factor (ECGF) and 20\% FBS. Cells were used at passage 2. Unless stated, HUVEC experiments were carried out in M199 (1\% FBS; 1\% pen/ strep).

\section{Tube formation assay}

To induce thin-layer angiogenesis (TLA) two approaches were taken: 1) Coverslip approach: $10 \mu \mathrm{l}$ of basement matrix (Geltrex $^{\mathrm{TM}}$, Life Science Technologies) (kept continuously

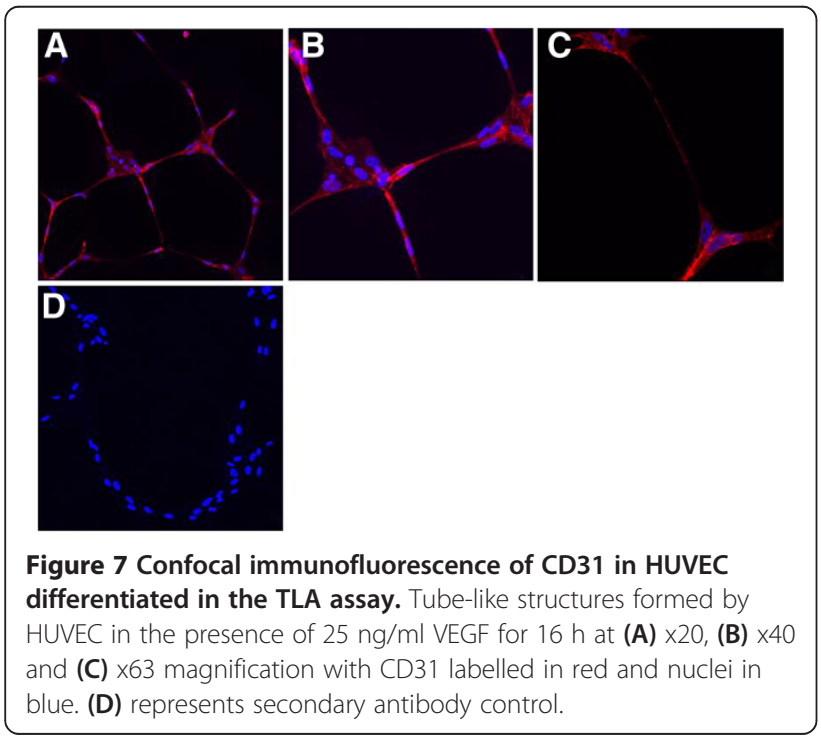

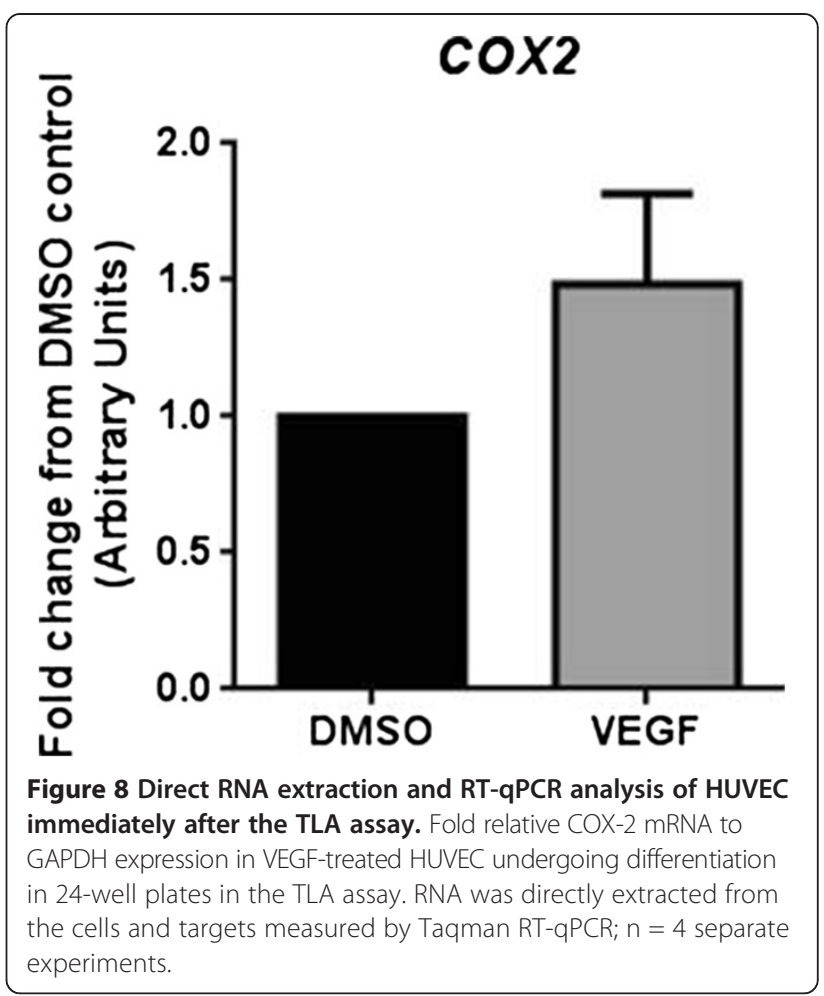

on ice) was placed on the centre of a $13 \mathrm{~mm}$ glass coverslip and spread evenly with the use of a cell scraper, providing a thin layer covering the surface of the coverslip. Each coverslip was subsequently transferred into the well of a 24-well plate (pre-cooled on ice) with the use of forceps. This process was repeated for each well before the gel was allowed to set at $37^{\circ} \mathrm{C}$ for 30 minutes. 2) Direct approach: $10 \mu \mathrm{l}$ of basement matrix was placed directly into the centre of each well of a 24-well plate and spread evenly with the rubber end of a sterile $1 \mathrm{ml}$ syringe insert. The plate was placed at $37^{\circ} \mathrm{C}$ for 30 minutes to allow the gel to set. After a $1 \mathrm{~h}$ serum-starvation in experimental media, cells were plated at a density of either 25,000 cells $/ \mathrm{cm}^{2}$ (HUVEC) or 100,000 cells $/ \mathrm{cm}^{2}$ (EA. Hy926) [3] and incubated for either 16 hours (HUVEC) [3] or 24 hours (EA.Hy926) in the appropriate experimental medium supplemented with either $25 \mathrm{ng} / \mathrm{ml}$ VEGF, $1 \mu \mathrm{M}$ GW0742 or $0.01 \%$ DMSO vehicle control (in duplicate). Phase-contrast images (4 images/well) were acquired using a Leica DMIRB inverted microscope $(\times 10$ magnification) and the mean number of branches/high powered field counted manually using image J software to form each n-number from each donor. For clarity, the structures routinely considered as branches for quantification purposes are highlighted in the accompanying Additional file 7: Figure S1. For automated quantification, images were analysed using the angiogenesis macro for ImageJ. 
To test scalability, the TLA assay was also performed in 96-well plates, using wells coated with $2 \mu \mathrm{l} /$ well of basement matrix, spread evenly with the use of an insert of a sterile Eppendorf $0.5 \mathrm{ml}$ combitip (cat \#: 0030089421). HUVEC were seeded at a density of 25,000 cells $/ \mathrm{cm}^{2}$ in experimental medium supplemented with $25 \mathrm{ng} / \mathrm{ml}$ VEGF, 100nM GW0742 or DMSO (vehicle) control (in sextuplet), and incubated at $37^{\circ} \mathrm{C} / 5 \% \mathrm{CO}_{2}$ for 16 hours. Phase-contrast images were acquired using a Leica DMIRB microscope ( $\times 10$ magnification) at the centre of each well and the number of branches counted manually following identification with ImageJ software.

For the comparison of the TLA assay with the traditional assay approach, HUVEC $\left(25,000\right.$ cells $\left./ \mathrm{cm}^{2}\right)$ were seeded onto either $2 \mu \mathrm{l} /$ well (TLA) or $50 \mu \mathrm{l} /$ well (traditional) of matrix in 96-well plates in the presence or absence of VEGF $(25 \mathrm{ng} / \mathrm{ml}$ ) and left to form tubes for 16 hours. Images were acquired using the Leica DMIRB inverted microscope as described above and average number of branches/high power field quantified manually using ImageJ software. For live imaging of cell differentiation, images were acquired every 30 minutes using Leica SP5 confocal microscope ( $\times 10$ objective).

\section{Microscopy}

HUVEC $\left(25,000\right.$ cells $\left./ \mathrm{cm}^{2}\right)$ were seeded into a $35 \mathrm{~mm}$ glass-bottom dish in which the glass area had been precoated with $10 \mu \mathrm{l}$ of Geltrex ${ }^{\mathrm{mm}}$ basement membrane and cells induced to undergo tube formation with VEGF (25 $\mathrm{ng} / \mathrm{ml} ; 16 \mathrm{~h})$. Medium was then replaced with fresh M199 containing 200nM MitoTraker green and the cells incubated for a further $40 \mathrm{~min}$ at $37^{\circ} \mathrm{C}$. Dye-containing medium was then replaced with fresh M199 prior to imaging.

Differential interference contrast (DIC) images were obtained using a Zeiss Axiovert 135 microscope fitted with a $\times 20$ objective. Confocal fluorescence images of mitochondria were obtained using a Leica SP5 confocal microscope fitted with a water emersion $(\times 63)$ objective. For z-stack series, images were obtained using a $\times 40$ objective and 3D images constructed using Volocity software (PerkinElmer; version 6.3.1).

\section{Immunocytochemistry}

The TLA assay was performed in 8-well chamber slides (LabTek) with HUVEC $\left(25,000\right.$ cells $\left./ \mathrm{cm}^{2}\right)$ seeded onto $3 \mu \mathrm{l}$ of Geltrex basement matrix in the presence or absence of $25 \mathrm{ng} / \mathrm{ml}$ VEGF. Tube-like structures were allowed to form for $16 \mathrm{~h}$. After the careful removal of media, cells were washed with PBS and then fixed with 4\% PFA for $10 \mathrm{~min}$. Cells were permeabilised with $0.1 \%$ Triton-x 100 , blocked in $3 \%$ BSA $1 \%$ goat serum for $30 \mathrm{~min}$, and CD31 detected using anti-CD31 rabbit polyclonal primary antibody $(1: 250 ; 1 \mathrm{~h}$ ) (Santa Cruz) and Alexa fluor 568 goat anti-rabbit secondary antibody
(30 min; Life Technologies). Cells were then mounted with DAPI-containing mounting media (Sigma, UK). Images were acquired with a Leica SP5 confocal fluorescence microscope. 3D images were constructed using Volocity software (PerkinElmer; version 6.3.1).

\section{RNA extraction and CDNA synthesis}

Total RNA was extracted using the on-column Qiagen (Manchester, UK) Total RNA Extraction kit as per the manufacturer's instructions. Briefly, media was removed from the wells by careful pipetting and any dead cells washed away with PBS. The plate was observed under a bright-field microscope to check for any disruption of cells. If no disruption was evident, $175 \mu \mathrm{l}$ of lysis buffer was added to each well and the resulting lysate was pooled for each treatment to achieve a final volume of $350 \mu \mathrm{l}$ of lysate per treatment. Lysates were put through a genomic spin column to remove as much genomic DNA contamination as possible. All remaining steps for RNA purification was performed by strict adherence to the manufacturer's instructions. RNA was eluted into $40 \mu \mathrm{l}$ of nuclease-free $\mathrm{H}_{2} \mathrm{O}$ and concentrations were determined using a NanoDrop-1000. cDNA was synthesised, as per manufacturer's guidelines using SuperScript ${ }^{\mathrm{TM}}$ II Reverse Transcriptase obtained from Invitrogen. Briefly, isolated RNA (equal amount per treatment) was combined with 1 $\mu \mathrm{l}$ of Oligo(dT) $(500 \mu \mathrm{g} / \mathrm{ml})$ and $1 \mu \mathrm{ldNTP}$ mix $(10 \mathrm{mM}$ each). The mixture was heated to $65^{\circ} \mathrm{C}$ for 5 minutes. Subsequently, a master mix consisting of $5 \mathrm{X}$ first-strand buffer, 0.1 M DTT and SuperScript ${ }^{\mathrm{Tx}}$ II Reverse Transcriptase $(100 \mathrm{U} /$ reaction) was added to the mixture to give a final reaction volume of $20 \mu \mathrm{l}$. The mixture was then heated to $42^{\circ} \mathrm{C}$ for 50 minutes before the reaction was inactivated by heating to $72^{\circ} \mathrm{C}$ for 15 minutes. cDNA was stored at $-20^{\circ} \mathrm{C}$ until further analysis.

\section{Quantitative RT-PCR}

Quantitative RT-PCR was performed using Taqman probe-based technology (Applied Biosystems) for cyclooxygenase (COX)-2 (Cat \# Hs01573477_g1) and the internal control gene GAPDH (Cat \# Hs02758991_g1). For each gene, a primer-probe master-mix and nuclease-free $\mathrm{H}_{2} \mathrm{O}$ was prepared and pipetted into each well of a 96-well PCR plate (18 $\mu \mathrm{l}$ /well). $2 \mu \mathrm{l}$ of cDNA sample was then added to the appropriate wells. A minus cDNA template $\left(\mathrm{H}_{2} \mathrm{O}\right)$ control was run for each gene. All reactions were performed in duplicate. The PCR reaction was run on a Chromo-4 machine using Opticon software under the following conditions: $50^{\circ} \mathrm{C}$ for $2 \mathrm{~min}, 95^{\circ} \mathrm{C}$ for $10 \mathrm{~min}$ followed by 40 cycles of $95^{\circ} \mathrm{C}$ for 15 seconds and $60^{\circ} \mathrm{C}$ for 30 seconds with a plate read at the end of each cycle. $\mathrm{C}(\mathrm{t})$ values were obtained at a cycle threshold value of 0.1. Results were normalised to GAPDH and analysed using the $\Delta \Delta C T$ method. 


\section{Statistical analysis}

All data are expressed as mean \pm SEM. Statistical differences were assessed by paired Student's $t$-test or repeated measures one-way ANOVA with Dunnett's post-analysis where appropriate. $p<0.05$ was considered statistically significant.

\section{Additional files}

Additional file 1: Table S1. Common parameters measured in the tube-formation assay as assessed by automated analysis software. Results of the automated analysis macro for ImageJ of tube-like structures formed by HUVEC seeded on to Geltrex-covered $(10 \mu \mathrm{l})$ coverslips in 24-well plates in the presence of VEGF $(25 \mathrm{ng} / \mathrm{ml})$, GW0742 $(1 \mu \mathrm{M})$ or DMSO (0.01\%) for 16 h. ${ }^{*} p<0.05$ vs. control as determined by paired Student's t-test.

Additional file 2: Movie S1. Live monitoring of HUVEC dynamics when plated on Geltrex basement matrix - TLA versus standard assay. HUVEC dynamics over $16 \mathrm{~h}$ when plated on Geltrex basement matrix in either the TLA assay $(2 \mu \mathrm{l} /$ well; A) or standard tube-formation assay $(50 \mu \mathrm{l} /$ well; B) in 96-well plates stimulated to undergo tubulogenesis with $25 \mathrm{ng} / \mathrm{ml}$ VEGF. Images were acquired using the Leica SP5 confocal microscope (x10 objective).

Additional file 3: Movie S2. Live confocal imaging of mitochondria in HUVEC tube-like structures from the TLA assay. Mitochondrial dynamics over $10 \mathrm{~min}$ (green) in tubes formed by HUVEC induced to undergo tubulogenesis by VEGF ( $25 \mathrm{ng} / \mathrm{ml} ; 16 \mathrm{~h}$ ). Images were obtained using Leica SP5 confocal microscope (x40 objective).

Additional file 4: Movie S3. 3D imaging movie of mitochondria in HUVEC tube-like structures from the TLA assay. 3D reconstruction of tubes with visible mitochondria (green) formed by HUVEC induced to undergo tubulogenesis by VEGF ( $25 \mathrm{ng} / \mathrm{ml} ; 16 \mathrm{~h})$.

Additional file 5: Movie S4. 3D imaging movie of CD31 (PECAM) in HUVEC tube-like structures from the TLA assay. 3D reconstruction of HUVEC stimulated to undergo tubulogenesis by VEGF $(25 \mathrm{ng} / \mathrm{ml})$ showing positive expression of CD31 (red) at the cell membrane. Images were acquired using Leica SP5 confocal microscope ( $x 40$ objective).

Additional file 6: Figure S2. RT-qPCR can be successfully performed on RNA extracted directly from HUVEC undergoing tubulogenesis in the TLA assay. Example of amplification plots demonstrating the successful detection and amplification of glyceraldehyde phosphate dehydrogenase (GAPDH) (A) and cyclooxygenase- 2 (COX-2) (B) by Taqman RT-qPCR and associated $C(t)$ values, $n=4$ separate experiments.

Additional file 7: Figure S1. Manual quantification of tubes using ImageJ software. Example of an original image of tube-like structures formed by HUVEC in the presence of VEGF (25 ng/ml; 16 h) (A) and after manual quantification using ImageJ (B) with Red markers highlighting individual branches.

\section{Competing interests}

The authors declare that they have no competing interests.

\section{Authors' contributions}

AF designed and performed the experiments, analysed the data and wrote the manuscript. RP designed and performed experiments and wrote the manuscript. AH performed the advanced microscopy and contributed to the manuscript. ST contributed to the writing of the manuscript. SL isolated and maintained HUVEC, and contributed to the writing of the manuscript. WH contributed to the writing of the manuscript. CWJ raised the funding, designed experiments and wrote the manuscript. DBB raised the funding, designed experiments and wrote the manuscript. All authors read and approved the final manuscript.

\section{Authors' information}

Caroline Wheeler-Jones and David Bishop-Bailey co-senior authors.

\section{Acknowledgements}

The authors would like to acknowledge Elaine Shervill for her skilled technical assistance with HUVEC isolation. RP and SL are supported by the Biotechnology and Biological Sciences Research Council (BB/J50015X/1 and $\mathrm{BB} / \mathrm{I005862/1}$, respectively; to (WJ) and ST is supported by the British Heart Foundation (PG/11/39/28890 to DBB).

\section{Author details}

${ }^{1}$ Comparative Biomedical Sciences, Royal Veterinary College, University of London Royal College Street, London NW1 OTU, UK. ²Diabetes and Nutritional Sciences Division, School of Medicine, King's College London, 150 Stamford Street, London SE1 9NH, UK.

Received: 14 July 2014 Accepted: 30 October 2014

Published online: 05 December 2014

\section{References}

1. Arantes RM, Andrews NW: A role for synaptotagmin VII-regulated exocytosis of lysosomes in neurite outgrowth from primary sympathetic neurons. J Neurosci 2006, 26(17):4630-4637.

2. Ma M, Ye JY, Deng R, Dee CM, Chan GC: Mesenchymal stromal cells may enhance metastasis of neuroblastoma via SDF-1/CXCR4 and SDF-1/ CXCR7 signaling. Cancer Lett 2011, 312(1):1-10.

3. Piqueras L, Reynolds AR, Hodivala-Dilke KM, Alfranca A, Redondo JM, Hatae T, Tanabe T, Warner TD, Bishop-Bailey D: Activation of PPARbeta/delta induces endothelial cell proliferation and angiogenesis. Arterioscler Thromb Vasc Biol 2007, 27(1):63-69.

4. Muses S, Morgan JE, Wells DJ: A new extensively characterised conditionally immortal muscle cell-line for investigating therapeutic strategies in muscular dystrophies. PLoS One 2011, 6(9):e24826.

5. Clarkin CE, King AJ, Dhadda P, Chagastelles P, Nardi N, Wheeler-Jones CP, Jones PM: Activin receptor-like kinase 5 inhibition reverses impairment of endothelial cell viability by endogenous islet mesenchymal stromal cells. Stem Cells 2013, 31(3):547-559.

6. Garonna E, Botham KM, Birdsey GM, Randi AM, Gonzalez-Perez RR, Wheeler-Jones CP: Vascular endothelial growth factor receptor-2 couples cyclo-oxygenase-2 with pro-angiogenic actions of leptin on human endothelial cells. PLoS One 2011, 6(4):e18823.

7. Staton CA, Reed MW, Brown NJ: A critical analysis of current in vitro and in vivo angiogenesis assays. Int J Exp Pathol 2009, 90(3):195-221.

8. Cooley LS, Handsley MM, Zhou Z, Lafleur MA, Pennington CJ, Thompson EW, Poschl E, Edwards DR: Reversible transdifferentiation of blood vascular endothelial cells to a lymphatic-like phenotype in vitro. J Cell Sci 2010, 123(Pt 21):3808-3816.

9. Pierce AD, Anglin IE, Vitolo MI, Mochin MT, Underwood KF, Goldblum SE, Kommineni S, Passaniti A: Glucose-activated RUNX2 phosphorylation promotes endothelial cell proliferation and an angiogenic phenotype. J Cell Biochem 2012, 113(1):282-292.

10. Michaelis M, Michaelis UR, Fleming I, Suhan T, Cinatl J, Blaheta RA, Hoffmann K, Kotchetkov R, Busse R, Nau H, Cinatl J Jr: Valproic acid inhibits angiogenesis in vitro and in vivo. Mol Pharmacol 2004, 65(3):520-527.

11. Zhao X, Lu X, Feng Q: Deficiency in endothelial nitric oxide synthase impairs myocardial angiogenesis. Am J physiol Heart Circ physiol 2002, 283(6):H2371-H2378.

12. Pendergrass W, Wolf N, Poot M: Efficacy of MitoTracker Green ${ }^{\mathrm{TM}}$ and CMXrosamine to measure changes in mitochondrial membrane potentials in living cells and tissues. Cytometry A 2004, 61A(2):162-169.

13. Staton CA, Brown NJ, Rodgers GR, Corke KP, Tazzyman S, Underwood JC, Lewis CE: Alphastatin, a 24-amino acid fragment of human fibrinogen, is a potent new inhibitor of activated endothelial cells in vitro and in vivo. Blood 2004, 103(2):601-606.

14. Staton CA, Lewis C, Bicknell R: Angiogenesis Assays: A critical appraisal of current techniques. UK: John Wiley \& Sons; 2007.

15. Capozzi ME, McCollum GW, Savage SR, Penn JS: Peroxisome ProliferatorActivated Receptor- $\beta / \delta$ Regulates Angiogenic Cell Behaviors and Oxygen-Induced Retinopathy. Invest Ophthalmol Vis Sci 2013, 54(6):4197-4207.

16. Wu G, Luo J, Rana JS, Laham R, Sellke FW, Li J: Involvement of COX-2 in VEGF-induced angiogenesis via P38 and JNK pathways in vascular endothelial cells. Cardiovasc Res 2006, 69(2):512-519. 
17. Logie JJ, Ali S, Marshall KM, Heck MM, Walker BR, Hadoke PW: Glucocorticoid-mediated inhibition of angiogenic changes in human endothelial cells is not caused by reductions in cell proliferation or migration. PLoS One 2010, 5(12):e14476.

18. Li A, Dubey S, Varney ML, Dave BJ, Singh RK: IL-8 Directly Enhanced Endothelial Cell Survival, Proliferation, and Matrix Metalloproteinases Production and Regulated Angiogenesis. J Immunol 2003, 170(6):3369-3376.

19. Vegran F, Boidot R, Michiels C, Sonveaux P, Feron O: Lactate influx through the endothelial cell monocarboxylate transporter MCT1 supports an NF-kappaB/L-8 pathway that drives tumor angiogenesis. Cancer Res 2011, 71(7):2550-2560.

20. Coutelle O, Hornig-Do HT, Witt A, Andree M, Schiffmann LM, Piekarek M, Brinkmann K, Seeger JM, Liwschitz M, Miwa S, Hallek M, Krönke M, Trifunovic A, Eming SA, Wiesner RJ, Hacker UT, Kashkar H: Embelin inhibits endothelial mitochondrial respiration and impairs neoangiogenesis during tumor growth and wound healing. EMBO Mol Med 2014, 6(5):624-639.

21. Schleicher M, Shepherd BR, Suarez Y, Fernandez-Hernando C, Yu J, Pan Y, Acevedo LM, Shadel GS, Sessa WC: Prohibitin-1 maintains the angiogenic capacity of endothelial cells by regulating mitochondrial function and senescence. J Cell Biol 2008, 180(1):101-112.

doi:10.1186/s12860-014-0041-5

Cite this article as: Faulkner et al:: A thin layer angiogenesis assay: a modified basement matrix assay for assessment of endothelial cell differentiation. BMC Cell Biology 2014 15:41.

\section{Submit your next manuscript to BioMed Central and take full advantage of:}

- Convenient online submission

- Thorough peer review

- No space constraints or color figure charges

- Immediate publication on acceptance

- Inclusion in PubMed, CAS, Scopus and Google Scholar

- Research which is freely available for redistribution 